\title{
Peculiar Features of the Tatar People Migration on the Territory of Tatarstan
}

Biktimirov N.

Kazan Federal University, Institute of Management, Economics and Finance, Kazan, 420008, Russia

Gabdrakhmanov N.

Kazan Federal University, Institute of Management, Economics and Finance, Kazan, 420008, Russia

Rubtsov V.

Kazan Federal University, Institute of Management, Economics and Finance, Kazan, 420008, Russia

Mustaphin M.

Kazan Federal University, Institute of Management, Economics and Finance, Kazan, 420008, Russia

Arzhantseva N.

Kazan Federal University, Institute of Language, 420008, Kazan, Russia

\section{Doi:10.5901/mjss.2014.v5n24p267}

\section{Abstract}

A specific feature of the Tatarstan Republic is the fact that the people living there are characterized by polyethnicity and multireligiousness. The development of the locals is predetermined by close ethnic and cultural interconnections and interpenetration of traditions the people of various nations living on this territory observe. Traditionally the leading role in this process was and is still played by Tatars and Russians, Muslims and Christians constituting the majority of the population there. In the recent decades the intensified migration processes in Tatarstan resulted in formation of numerous groups of people coming from former Soviet Republics (the Azerbaijani, the Armenians, the Uzbeks, the Tadjiks, the Kazakhs, the Georgians, the Moldavians, the Turkmens) as well as national groups from the regions of the Russian Federation and distant foreign countries (the Turks, the Vietnamese, the Arabs, etc.) which are a little smaller in population (several hundred people). The role of the ethnic factor in the demographic potential hasn't been properly investigated mostly because of the lack of the published demographic statistics concerning the ethnic aspect and also because of the difficulty to reveal the interrelations of this factor with other ones. The aim of the research has been identified as to reveal the territorial and historical peculiarities of the Tatar population settling on the territory of modern Republic of Tatarstan, to reveal its tendencies, to estimate the significance of the ethnic factor in formation and development of the demographic potential. This research has revealed the rapprochement of the demographic behaviour of the people of different nationalities (especially Russians and Tatars) as one of the most important tendencies of the demographic development of the population. The reason for this has been the rapprochement of the results of the demographic behaviour of the people of different nationalities (especially Russians and Tatars) as the result of the loss of national values and traditions, religious background assumptions, customs, ceremonials, etc.

Keywords: the Kazan Khanate, Tatars, system of migration, Tatarstan Republic, ethnic demography.

\section{Introduction}

The nations living on the territory of Tatarstan are presented by the following Volga Region peoples: 126.5 thousand (3.3\%) Chuvashes, 24.2 thousand (0.6\%) Udmurts, 23.7 thousand (0.6\%) Mordovians, 18.8 thousand (0.5\%) Mari and 14.9 thousand $(0.4 \%)$ Bashkirs, i.e. $5.1 \%$ of the population of Tatarstan. The Ukranians 24 thousand people $(0.6 \%)$, Byelorussians - 6.1 thousand (0.2\%), Jews - 3.5 thousands (0.1\%), Germans - 2.9 thousands (0.08\%), Polish - 620 people $(0.02 \%)$ and others have been living on the territory for a long time (Gaisin and Biktimirov, 2014).

We should note the works of such researchers as N.Biktimirov, E.Busygin, G.Galieva, G.Galiullina, F.lldarkhanova, D.Iskhakov, D.Kurganova, N.Makhmutova, M.Mustaphin, L.Khadieva, Ch.Shafranskaya, etc. who paid their utmost 
attention to the demographic behaviour of different ethnic groups inhabiting the Tatarstan Republic.

M.Mustaphin gave a detailed characteristics of the settlement of the main nations (Мустафин, 1993). At those times the Tatar population constituted 48.5\%, and the Russian - 43.5\%. During the period of 1979-1989 the proportion of the Russians lowered from $44 \%$ to $43.5 \%$, and of the Tatars grew from $47.6 \%$ to $48.5 \%$. Mostly it was connected with a smaller migration activity of the Tatar people and higher rates of their natural population growth (Gaisin et al., 2014).

In accordance with the results of the All-Russian nationwide census of 2002 Tatarstan is presented by 115 ethnicities. On the territory of Tatarstan there live 3.8 million people, $52.9 \%$ of whom are Tatars, $39.5 \%$ - Russians. These two ethnicities whose languages are proclaimed as the state ones constitute the absolute majority (92.4\%) of the republic population.

\section{Methodology}

A thorough study of ethnic and demographic problems of the modern territory of the Tatarstan Republic is only possible when using the methodology of sociology, geography, mathematics. Such approach gives an opportunity to reveal the role and the place of ethnic and demographic problems in the societal development. The methodology applied in this research substantiates the opportunity and necessity to modernize the sociological study of ethnic and demographic problems in the Tatarstan Republic by singling out ethnodemography as a separate sociological theory on the borderline of ethnography, demography and sociology.

Using the best practice and experience of geodemography and ethnodemography we define the essence of ethnogeodemographic research as the study of demographic processes and structures differentiated by an ethnic attribute from the geographic aspect. The geographic positions presuppose the analysis of territorial differences of homotypic demographic indicators of a particular ethnic group and the analysis of ethnic differences of homotypic demographic indicators on a particular territory. In a broad sense ethnodemography as any other science has to deal with the development in methodology beside the geographic analysis. The application of geographic principles to ethnodemography brings us to the uprise of such specific concept as an ethnodemographic situation. We could define an ethnodemographic situation as a complex qualitative and quantitative estimation of ethnodemographic processes and structures of a particular territory interacting with the surrounding natural and social environment (Орлов, 2009).

\section{Results}

The geography of Tatar settlements on the territory of the Republic of Tatarstan has its peculiarities. Even in the 20s of the $20^{\text {th }}$ century it was impossible to find Tatar settlements in the Volga basin and in the cities located on the territory of this area. The explanation comes from the historic events which happened after the Kazan Khanate joined the Russian State in 1552. The Edict of Ivan the Terrible ordered to send Tatars 50 versts (a Russian unit of distance equal to 1.067 $\mathrm{km}$ or 0.6629 mile) into the depth of the area.

There existed 3 main natural areas for settling, or territorial concentration of people in this period. Firstly, it's Zakazanye (North-Western part of the Kazan Khanate), which historically is the territory of Tatar people, the arena for forming its national community. Secondly, Tatars have been living in the western part of Predvolzhye (Western part of the Kazan Khanate) for a long time. This is the reason to see this territory as the second largest array for Tatars settling. Historically, the main belt for Tatars settling - Zakazanye, Predkamye (the northern part of the Kazan Khanate, quite a scanty region of the republic) - was formed in the period of XV-XVI centuries.

The third array is located in the outermost Eastern part of the Tatarstan Republic. By the way, nowadays in many administrative districts of these regions the number of inhabitants exceeds 90\%. The accumulation of the net of Tatar settlements in the eastern part of the republic is closely connected with the spontaneous migration of Tatars from Zakazanye and Predvolzhye after the Kazan Khanate was joined to the Russian State.

The consistent pattern of the dependence of the peoples settlement on the ethnic composition is still preserved. For example, the location of settlements depending on the geomorphological peculiarities of the territory had ethnic differences at the end of XVIII century. So in Sviyazhskyi Uyezd there were 69\% Russian rural settlements, $50 \%$ Chuvash and only $26 \%$ Tatar located on banks, $26 \%$ - at springs, wells and swamps, $5 \%$ - at ravines. Across most Tatar villages there flew small rivers or springs. Some ethnologists mentioned that Tatars disliked to dig out wells.

The development of the Soviet system had a positive effect on the migration processes of Tatar people. It might be explained by the fact that provinces were the administrative settlement units in Russia before the revolution. The administrative-territorial division in pre-revolutionary Russia didn't take into account the conditions of dense inhabitancy of non-Russian ethnic groups on the territory of Russia. At that time certain districts on the territory of modern Tatarstan 
belonged to 5 provinces: Kazan, Vyatka, Ufa, Samara and Simbir. At this period the leading ethnic groups in Kazan province were Tatars and Russians, then there prevailed Chuvashes, Bashkirs, Mordovians and Votyaks (Udmurts) living in all territorial subdivisions. In 1920 after the Tatar Republic was formed Tatars constituted more than half the population (table1).

Table 1. Ethnic composition of the population of Tatarstan Republic according to the census of 1920.

\begin{tabular}{|c|c|c|c|c|c|c|c|c|}
\hline \multirow{2}{*}{ Groups of people } & \multirow{2}{*}{$\begin{array}{c}\text { Number } \\
\text { (thousands of people) }\end{array}$} & \multicolumn{6}{|c|}{ Including (\%) } \\
\cline { 3 - 9 } & & Tatars & Russians & Chuvashes & Mordovians & Udmurts & Marii & others \\
\hline Rural & 2639 & 54,8 & 36,9 & 5,3 & 1,5 & 0,9 & 0,5 & 0,1 \\
\hline Urban & 253 & 16,3 & 78,3 & 0,3 & - & - & 0,1 & 5,0 \\
\hline Total & 2892 & 51,6 & 40,4 & 4,9 & 1,5 & 0,8 & 0,4 & 0,2 \\
\hline
\end{tabular}

The most important event of the 20s of XX century is certainly the famine in 1921-1923, which brought the most harm to people and their migration in the Kalmyk and Tatar Republics, Chuvash and Marii regions, Chelyabinsk province where $90 \%$ of people suffered, $70 \%-90 \%$ of population starved in the Bashkir Republic.

As it has been mentioned, the Tatar Republic was among the regions which suffered greatly from the famine. The population composition changed greatly between the two censuses, which was conditioned by a big population decline.

Firstly, we paid our attention to the year of 1921, the time for mass spread of drought on the studied territory. According to the statistics the rural population of Tatarstan, which constituted the major part of the republic inhabitants from 1920 to 1926, decreased for 326.1 thousand people due to the rise of mortality. Among them there were $77.7 \%$ of Tatars, $16.9 \%$ of Russians and $5.4 \%$ of national minorities. Due to the geographic factor, the specifics of the ethnic groups settlement (low percentage of Tatars in cities and on the adjoining territories which got food aid) and economic indicators (absence of material assets and underdevelopment of vegeculture) the number of Tatars decreased by $17.5 \%$ (253.5 thousand people), Russians - by 5.7\% (55.3 thousand people) and national minorities - by $8 \%$ (17.3 thousand people).

Especially big was the harm brought to the people living in the south regions of the republic. Differentiating greatly in regions the maximum growth in mortality of Tatars (35.7\%) was found out in Spasskyi Canton in the south of Tatarstan Republic. Nearly 300-500 thousand of famine refugees left the republic. These figures exceed largely the people loss during the World War II (450 thousand). Such a high degree of national differentiation of demographic statistics wasn't marked even in the years of 1941-1945.

Underdevelopment of vegeculture for Tatars could be explained by a little usage of vegetables; for example, Tatar peasants rarely cooked vegetable soup and didn't make pickles. Besides, the marketable products were unprofitable due to the remoteness of Tatar areas from cities.

\section{Discussions}

The problem of stability or changeability of ethnic and regional identity in the conditions of globalization of the world development gets the leading position in the ethnodemographic researches. However, subtlety and delicacy of the very fact of the ethnicity change hinder regular statistics researches and publication of results, for example, in the materials of population census. It's worthy to note some of the works which reveal the essence of the assimilation processes in polyethnic environment. First of all, these are the works of outstanding ethnologists of Soviet and post-Soviet periods (Бромлей, 1983; Брук, 1986; Гумилев, 2001; Тишков, 2003). The most significant researches of the processes of changing of ethnic identity in the demographic aspect which revealed the degree of the assimilating role of the Russian ethnos were made in the Institute for Socio-Political Research RAS and the Centre for Demography and Human Ecology of Institute of Economic Forecasting RAS. For the first time the scientists documented the level of interethnic nuptiality. The correlation between natural, migration and identification growth of the number of ethnic groups determines the dynamics of ethnodemographic composition of the population of the region. The pace of the dynamics of ethnodemographic structure of the population (which takes into account the changes for a unit of time) plays an important role as the indicator characterizing the tendencies of ethnodemographic processes. Besides, the dynamic measurement in ethnodemography implies the spread of the types of demographic regimes of reproduction of population. For this it will be important to compare the tendencies for demographic transformations in geographic space. 


\section{Statements}

Studying the demographic statistics for the two main nations in the Republic of Tatarstan it might be noted that for a long time the birthrate among the Tatar population was 1.4 times higher and the death rate was 1.5 times lower than among Russians. The differences in the level of mortality among Russian people in cities 1.8 times exceeded the similar rates for urban Tatars. There also might be observed the differences in the rates of nuptiality and divorces. So the divorce rate among Tatars was 1.7 times lower than among Russians. Concerning the balance of migration various stages of republic development there marked by essential ethnic differences mainly in favour of Tatars. For example, in 1992 the balance of migration of Tatars 4.7 times exceeded the balance of migration of Russians.

These advantages in ethnodemographic development of Tatars played their compensating role as the response to the utterly negative consequences of the drought, and even to the consequences of the events of the year of 1552 . Tatars started to migrate everywhere. The number of inhabited localities with plural population has been growing from the 20s of the XX century. For example, 55 inhabited localities with plural population (7.6\%) were recorded in 1948 in Predvolzhye alone. These were mainly workers settlements.

During the years of the Soviet government in the valley of the Volga and the Kama there appeared a whole range of new Tatar settlements reviving the historical picture: Vatan, Idel, Nariman, Kzyl Bairak, Bakhcha-Sarai.

While studying the objective laws of changing of the national composition of rural inhabited localities during the period of two censuses from 1970 to 1989 we processed the statistical data to study the objective laws of the population dynamics. We found out that in rural inhabited localities (in 55 of which Russian population prevailed earlier), Tatar population started to prevail in number by the year 1989. It is proved by their growth from 27034 to 28473 people. Among the studied objects there are 29 plural settlements with Tatars prevailing (52.7\%), 5 of them are located close to railways, 18 are close to drainage network, and almost all of them are located close to administrative centres $(1-3 \mathrm{~km})$. While analyzing we found out another variant of the change in national composition, for example, Tatars - Russians. The number of people in 15 inhabited localities of the republic lowered from 4364 to 3170 people during the studied period. 10 inhabited localities out of the 15 mentioned above have mixed composition (66\%), 5 of them are relatively monoethnic.

There exist 19 cases of the changes in national composition. We suggest the most widespread:

Russians $\rightarrow$ Chuvashes + Russians ( 6 is the number of inhabited localities)

Chuvashes $\rightarrow$ Russians + Chuvashes (6)

Chuvashes $\rightarrow$ Tatars (3)

The biggest number of inhabited localities subject to changes in the case "Russians - Tatars"(12) have the population size of 200-500 people (27.3\%), in the case "Tatars - Russians" (5) - 100-200 people (33\%), in the case "Russians - Tatars" the maximum population growth is observed with 2-times increase in variant II (50-100 people), the maximum population decrease is characteristic for variant II (0-50 people) with the 4.5-times decrease. In the case "Tatars - Russians" the maximum (500-1000 people) is 1.07 times and the minimum (50-100) is 2.59 times (table 2).

Table 2. Changing of the population of human settlements according to ethnic composition during 1970 - 1989 (absolute measures).

\begin{tabular}{|c|c|c|c|c|c|c|}
\hline \multirow[b]{2}{*}{$\begin{array}{l}\text { Groups of inhabited } \\
\text { localities }\end{array}$} & \multicolumn{3}{|c|}{ Russians - Tatars } & \multicolumn{3}{|c|}{ Tatars - Russians } \\
\hline & $\begin{array}{c}\begin{array}{c}\text { Number of } \\
\text { changes }\end{array} \\
\end{array}$ & \multicolumn{2}{|c|}{$\begin{array}{c}\text { Change in the number of } \\
\text { inhabitants }\end{array}$} & $\begin{array}{c}\text { Number of } \\
\text { changes }\end{array}$ & \multicolumn{2}{|c|}{$\begin{array}{c}\text { Change in the number of } \\
\text { inhabitants }\end{array}$} \\
\hline \multirow{2}{*}{$\begin{array}{c} \\
\text { ( } 0-50) \\
\text { people. }\end{array}$} & \multirow[t]{2}{*}{ o. } & 123 & 27 & \multirow[t]{2}{*}{ 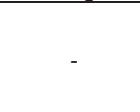 } & - & - \\
\hline & & \multicolumn{2}{|c|}{ - 4,5 times. } & & \multicolumn{2}{|c|}{-} \\
\hline \multirow{2}{*}{$\begin{array}{c}\text { II } \\
(50-100) \\
\text { people. }\end{array}$} & \multirow[b]{2}{*}{8} & 585 & 1215 & \multirow[b]{2}{*}{4} & 321 & 124 \\
\hline & & \multicolumn{2}{|c|}{ + 2,07 times. } & & \multicolumn{2}{|c|}{ - 2,59 times. } \\
\hline \multirow{2}{*}{$\begin{array}{c}\text { III } \\
(100-200) \text { people. }\end{array}$} & \multirow{2}{*}{12} & 1552 & 1485 & \multirow{2}{*}{5} & 689 & 566 \\
\hline & & & & & \multicolumn{2}{|c|}{$-1,22$ times. } \\
\hline \multirow{2}{*}{$\begin{array}{c}\text { IV } \\
(200-500) \text { people. }\end{array}$} & \multirow{2}{*}{15} & 4563 & 5716 & \multirow{2}{*}{3} & 1015 & 641 \\
\hline & & & & & \multicolumn{2}{|c|}{$-1,58$ times. } \\
\hline \multirow{2}{*}{$\begin{array}{c}\mathrm{V} \\
(500-1000) \\
\text { people. } \\
\end{array}$} & \multirow{2}{*}{10} & 7074 & 5935 & \multirow[b]{2}{*}{2} & 1295 & 1395 \\
\hline & & \multicolumn{2}{|c|}{ - 1,2 times. } & & \multicolumn{2}{|c|}{ +1,07 times. } \\
\hline \multirow{2}{*}{$\begin{array}{c}\mathrm{VI} \\
\text { (1000) and more people. }\end{array}$} & \multirow{2}{*}{7} & 13050 & 14841 & \multirow[t]{2}{*}{1} & 1044 & 444 \\
\hline & & & & & \multicolumn{2}{|c|}{$-2,35$ times. } \\
\hline
\end{tabular}




\section{Conclusion}

1. Urbanization of Tatars will continue to grow quickly, the places for their settlement will become big cities and agglomerations. A substantial growth of the number of Tatars in big cities and regions with relatively high living standards is forecasted.

If we compare the statistics of 1989 and 2002 within Tatarstan, we'll see that the part of urban inhabitants among Tatars has become bigger by $3.5 \%$, and Russians only by $0.5 \%$.

2. Russians are less inertial in their demographic behavior than Tatars (Gabdrakhmanov, 2011). And Tatars have a bigger influence on the formation of new tendencies in the demographic development of the republic population. The new generations of Tatars still have a feebly marked national conscience, and, on the other hand, the popularization of Islam and the support of the Muslim world can also play an important role in strengthening of the Turkic and Muslim identity of Tatars.

3. The most favourable places for the population growth of Tatars should be considered the inhabited locations with the population of 50-100 and 200-500 people, and those where the population is bigger than 1000 people (Gabdrakhmanov and Rozhko, 2014). And vice versa, these very groups of settlements show negative statistics for Russians. The only favourable place for the population growth of Russians is the settlement with the population of $500-1000$ people.

4. Settling of people on the territory of modern Tatarstan was ethnically determined (Bagautdinova et al., 2013). The investigation of the changes of ethnic composition of rural inhabited locations of Tatarstan during 19701989 shows the tendency to revive the historical picture of people settling by creating a whole range of new Tatar settlements on the place of the Russian ones.

\section{References}

Bagautdinova, N.G., Panasyuk, M.V., Gafurov, I.R. Wavelet analysis of the territorial socio-economic system dynamics // World Applied Sciences Journal, 27(13), 2013, 62-66.

Fakhrutdinova, E., Karasik, E., Safina, L., Miropol'skaya, N. The role of social protection in formation of quality of work life// World Applied Sciences Journal.Volume 27, Issue 13, 2013, Pages 72-76.

Fakhrutdinova, E., Safina, L., Kolesnikova, J., Fedor, Mikhailov. Quality formation of working life of the youth// World Applied Sciences Journal. Volume 27, Issue 13, 2013, Pages 87-91.

Gabdrakhmanov N.K. Social and economic premises for family formation in the Republic of Tatarstan // The Family in the Modern World: Materials of international scientific conference. - Helsinki; University of Helsinki, 2011 - P.80-85.

Gaisin R.I., Gaisin I.T., Biktimirov N.M. The use of new methodologies for demograpfic investigation in national territorial subdivisions of Russia. Life Sci J 2014; 1 I(8s): 194-197

Ilgizar Timergalievich Gaisin and Niaz Minnahmatovich Biktimirov. Migration Processes in the Republic Tatarstan in the Second Half of the 20th and in the Early of 21st Centuries: Ethnic and Social Aspects. Middle-East Journal of Scientific Research 20(12):1761 1766,2014

Gabdrakhmanov N.K. and Rozhko M.V. Positioning of Volga Federal District Regions by Demographic Situation Index // World Applied Sciences Journal, Volume 30 Number 6, 2014. - pp.792-795

Niyaz Gabdrakhmanov, Dmitriy Egorov Report «The role of geo-demographic infrastructure facilities in the regional development of human capital» // WARSAW REGIONAL FORUM 2013 Territorial capital - concepts, indicators and policy by the Institute of Geography and Spatial Organization Polish Academy of Sciences, together with the Ministry of Regional Development of the Republic of Poland and Polish Geographical Society, Warsaw, p. 57 // October 2013

Panasyuk, M.V., Dzasaeva, R.D., Shaidullin, R.N., Anopchenko, T.Y. Problems of modernization of the health economics in the russian regions // World Applied Sciences Journal, 27(13), 2013, 154-158.

Safiullin M.R., Elshin L.A., Shakirova A.I., Ermolaeva P.O., Prygunova M.I. (2013). Influence of Territorial Ecological Load Factors on Social and Economic Well-Being of Population: Methodology Development and Econometric Model Construction. World Applied Sciences Journal 25, 7, 1057-1061.

Biktimirov N.M. Demograficheskiy prognoz tatarskoy chasti naseleniya Rossii. Sbornik II Vserossiyskoy nauchno-prakticheskoy konferentsii s Mezhdunarodnyim uchastiem "Geografiya v polikulturnom mire" 3-4 marta 2014 g. / Otv. red. G.S. Samigullina Kazan, Otechestvo, 2014.- $226 \mathrm{~s}$.

Bromley Yu. V. Ocherki teorii etnosa. - M.: Nauka, 1983. - $412 \mathrm{~s}$.

Bruk S. I. Naselenie mira: etnodemograficheskiy spravochnik. — M.: Progress, 1986. - $828 \mathrm{~s}$.

Gumilev L. N. Etnogenez i biosfera Zemli. - M.: Rolf, 2001. - 560 s.

Mustafin M.R. Geografiya naseleniya i naselennyih punktov Tatarstana. - Kazan: Kazan, 1993. - 80 s.

Orlov A.Yu. Metodika etnogeodemograficheskih issledovaniy // Geografiya i prirodnyie resursyi. 2009. \# 1. S. 138-143. 